\title{
Did Emperor Moctezuma II's head injury and subsequent death hasten the fall of the Aztec nation?
}

\author{
Gonzalo M. Sanchez, MD
}

Tucson, Arizona

This article analyzes the head injury of Emperor Moctezuma as one of those injuries that affected the course of history. The Emperor's death arguably changed the fate of an entire nation and led to the destruction of the Aztec civilization.

Moctezuma died in the evening hours of June 30,1520, in his palace in the Aztec capital, Tenochtitlan, while a prisoner of the Spanish conquistadors. The Emperor had been speaking to his people in an effort to persuade them to cease hostilities against Hernán Cortés, his Spanish soldiers, and Indian allies. Both Spanish and Indian contemporary sources document that he sustained a severe head injury when one of his own warriors hit him with a rock thrown from a sling. However, after the Conquest of Mexico some of the information collected by Spanish friars from Indian stories, songs, and pictorial representations raised the possibility that Moctezuma died of strangulation or stabbing at the hands of the Spaniards. There is even a suggestion of suicide. This issue remains unresolved and emotionally charged.

The historical and clinical analysis of the events surrounding Moctezuma's death indicates that the Emperor most likely died as a consequence of head injury. The author has attempted to present a neutral analysis but agrees with Benjamin Keen that neutrality may be unattainable, no matter how remote the subject of historical inquiry is from the present.

http://thejns.org/doi/abs/10.3171/2015.4.FOCUS1593

KEY WORDS Moctezuma death; head injury; sling

$\mathrm{B}$ y 1518 Moctezuma (variously spelled in the literature as Motezuma, Motecuhzoma or Montezuma) (Fig. 1), the famous last emperor of the powerful Aztec nation, had ruled that empire for 17 years. He was known as an able commander and judge who achieved greatness by major victories as head of both the army and the Aztec religion in an empire that stretched from the Pacific Ocean to the Gulf of Mexico and as far south as present-day Guatemala.

When Hernán Cortés landed with his troops on April 22,1519 , on the Gulf coast (at present day Veracruz), he was seen by Moctezuma as the previously vanquished god Quetzalcoatl coming to reclaim his throne. Quetzalcoatl was an important Aztec god who opposed human sacrifice and was in direct conflict with the sun gods Tezcatlipoca (spiritual guardian of the Aztecs) and the warrior sun god Huitzolopochtli (another manifestation of Tezcatlipoca), who required continuous blood sacrifices. According to legend, Quetzalcoatl had promised to return on a certain anniversary date to the east coast of Mexico, whence he had departed. Aware of various celestial events interpreted as ominous portents by Moctezuma and his magicians, the emperor had ordered a continuous watch of the east coast for signs of Queztalcoatl's return. On May 15, 1518, Moctezuma received news of large vessels seen off the Gulf coast and of landing parties of strange men. One year later (April 1519), Cortés' arrival to the coast coincided with the predicted anniversary of Quetzalcoatl's return. The emperor thus found himself in what he saw as a battle against a supernatural foe. ${ }^{2}$

On August 8th, 1519, Cortés and his army of Spanish conquistadores began their invasion of Mexico from the east coast. With lavish gifts Moctezuma unsuccessfully tried to prevent Cortés and his troops from advancing towards his capital city of Tenochtitlan. Cortés made alliances with the Cempoalan peoples. With others, such as the Tlaxcalans and the Cholulans, he waged victorious battles using firepower, steel weapons, horses, and war dogs. These actions were nervously followed by Moctezuma's informants and reinforced the Emperor's belief in 


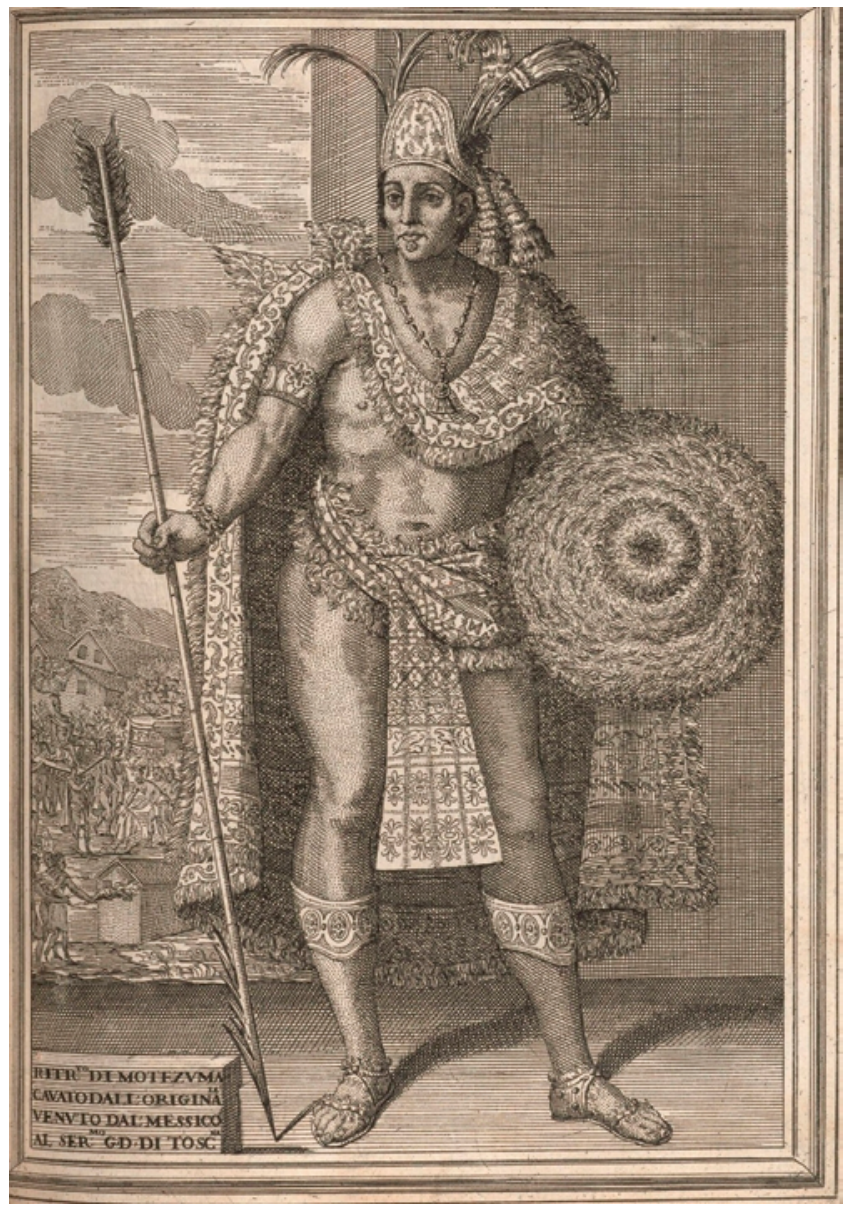

FIG. 1. "Moctezuma II" from de Solís, A. Istoria della conquista del Messico, della popolazione, e de' progressi nell'America Settentrionale conosciuta sotto nome di Nuova Spagna. Florence: Stamperia di S. A. S. per G. F. Cecchi, 1699. Source: Typ 625.99.800, Houghton Library, Harvard Source. Public domain.

the conquistadores' stature as gods and the inevitability of their march into Tenochtlitlan. This led the Emperor to welcome the newcomers into Tenochtitlan on November 8, 1519. Moctezuma provided food and quarters for those he believed to be the gods. As 5 months went by, acts of disrespect for the Aztec gods and the Spaniards' abhorrence of human sacrifice gradually turned the populace against the Spaniards. By late May 1520, the Spaniards, feeling extremely vulnerable, made the bold move of making the Emperor their prisoner in his own palace, under the pretext that Moctezuma had ordered the killing of some Spanish soldiers. The Emperor's humiliation and an alleged unprovoked attack and massacre of the Mexica nobility prompted a full-scale revolt by the Aztec warriors, which inflicted heavy casualties on the Spanish.

Fighting against overwhelming odds and with unrest within his own camp, Cortés decided to withdraw from the Aztec capital. ${ }^{6,23,25} \mathrm{He}$ requested that Moctezuma address his people, ${ }^{3,12,18,19,27}$ so that they would allow the Spaniards to leave; Moctezuma reluctantly agreed. ${ }^{23}$ In the Aztec ranks this was seen as betrayal, and the warriors began hurling stones, spears and arrows at the Emperor (Fig. 2). Moctezuma died in the evening hours of June 30,
1520, in his palace in Tenochtitlan while being held as a prisoner of the Spanish.

Both Spanish and Indian ${ }^{6}$ sources of the time documented that Moctezuma received a severe head injury from a sling shot from those of his own people whom he was addressing in his attempt to persuade them to cease hostilities against Cortés and his Spanish soldiers and Indian allies. However, after the conquest, some of the information that Spanish friars collected from Indian stories, songs, and pictorial representations raised the possibility that Moctezuma died of strangulation or stabbing at the hands of the Spaniards. There is even a suggestion of suicide. This issue remains unresolved and emotionally charged. ${ }^{15,16,26}$

In order to consider the validity of Moctezuma's death from a head injury, it is imperative to analyze the historical as well as the scant clinical data. Similar attention is demanded of the analysis of theories of Moctezuma's possible execution by the Spaniards (not the main purview of this work).

Where prior translations are not available, I have translated the Spanish sources and have also added a minor revision to Patricia de Fuentes' 7 translation of the chronicle of Fray Francisco de Aguilar and translated a sentence in Muñoz Camargo's Historia de Tlaxcala.

\section{Evidence Review Historical Documentation}

Both versions of the story of Moctezuma's death, whether at the hands of the Aztecs or the Spaniards, are cited in the following sources produced in the late 16th and early 17 th centuries:

On October 30, 1520, 4 months after Moctezuma's death, the captain of the Spanish conquistadors, Hernán Cortés, ${ }^{3}$ reported in his second Carta de Relación to Emperor Charles V regarding the circumstances of Moctezuma's addressing his subjects:

I had taken him out, and then he reached a breastwork which ran out beyond the fortress, and was about to speak to them, [when] he received a blow on his head from a stone; and the injury was so severe that he died three days later...

Concordant and detailed accounts about this event are given by witnesses to the event, Bernal Díaz del Castillo ${ }^{10}$ (Historia verdadera de la Conquista de la Nueva España, 1568), Francisco de Aguilar., ${ }^{1,7}$ (Relación Breve de la Conquista de Nueva España, 1565), and Bernardino Vázquez de Tapia ${ }^{27}$ (Relación de Méritos y Servicios del Conquistador Bernardino Vázquez de Tapia, 1542).

From Bernal Diaz del Castillo, Spanish soldier and author, who participated in the conquest of Mexico: ${ }^{4}$

Montezuma was placed by a battlement of the roof with many of us soldiers guarding him, and he began to speak to his people, with very affectionate expressions telling them to desist from the war, and we would leave Mexico. Many of the Mexican Chieftains and Captains knew him well and at once ordered their people to be silent and not to discharge darts, stones or arrows, and four of them reached a spot where Moctezuma could speak to them, and they to him, and with tears they said to him: "Oh Señor and our great Lord, how all your misfortune and injury of that of your children 


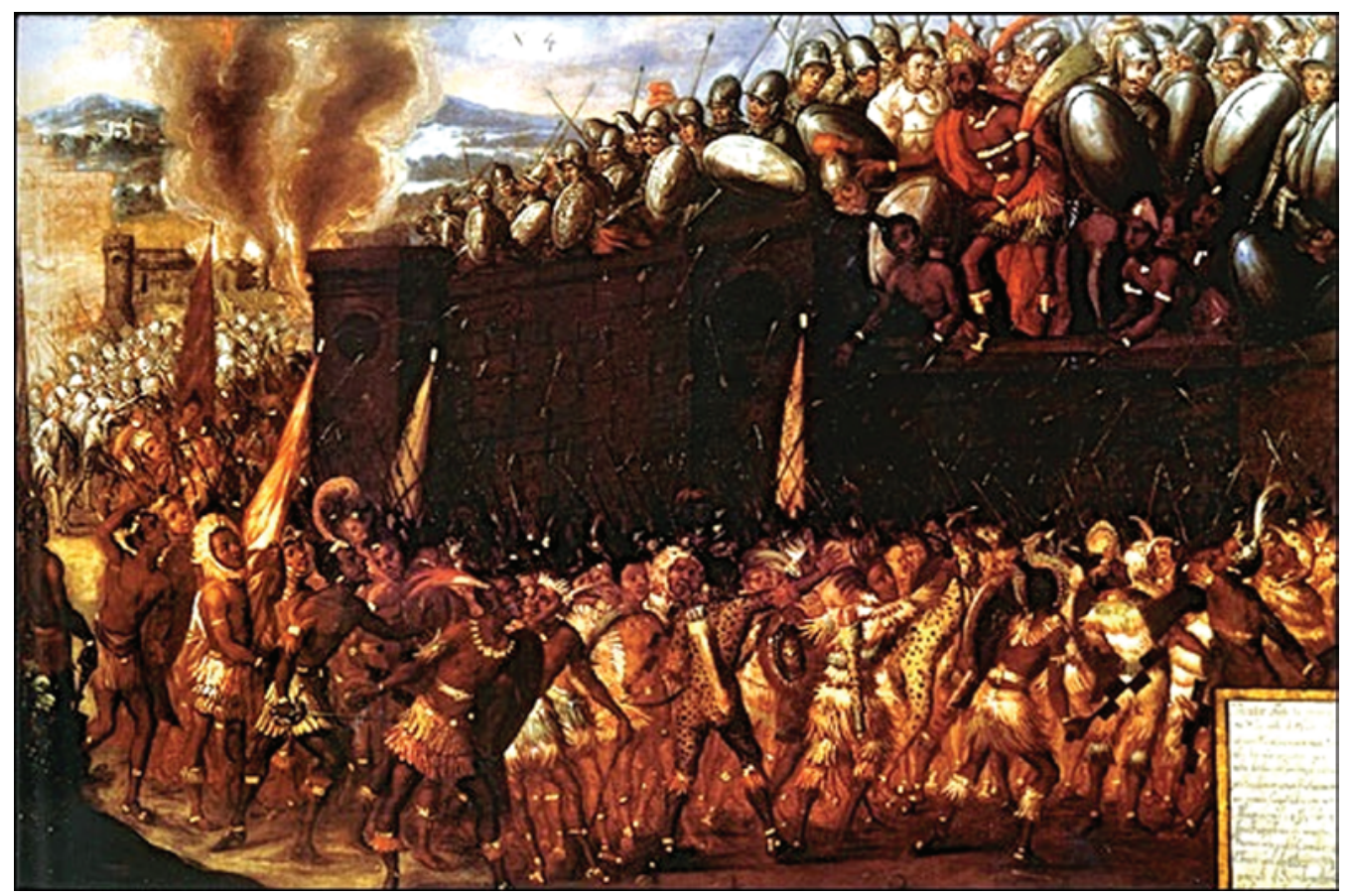

FIG. 2. "The death of Moctezuma at the hands of his own people." Unknown artist. The Library of Congress, The Conquest of Mexico Paintings, Painting 4. The farthest Aztec warrior on the left, lower row, is in the process of throwing a stone with his "tematlatl" (sling). Source: http://www.loc.gov/exhibits/exploring-the-early-americas/interactives/conquest-of-mexico-paintings/painting4/. Public domain.

and relations afflict us, we make known to you that we have already raised one of your kinsmen to be our Lord," and there he stated his name, that he was called Cuitlahuac, the Lord of Ixtapalapa, and moreover they said that the war must be carried through, and that they had vowed to their Idols not to relax it until we were all dead, and that they prayed every day to their Huchilobos and Texcatepuca (Huitzolopochtli and Tazcatlipoca) to guard him free and safe from our power, and that should it end as they desired, they will not fail to hold him in higher regard than they did before, and they begged him to forgive them. They had hardly finished this speech when suddenly such a shower of stones and darts were discharged that (our men who were shielding him having neglected for a moment their duty, because they saw how the attack ceased while he spoke to them) he was hit by three stones, one on the head, another on the arm and another on the leg, and although they begged him to have the wounds dressed and to take food, and spoke kind words to him about it, he would not. Indeed, when we least expected it, they came to say that he was dead.

This description was provided by Francisco de Aguilar, ${ }^{1}$ a soldier who became a Dominican friar after the conquest:

And so the Captain, well shielded with a steel buckler, and Cervantez the Commendador, covered by a leather shield, stayed in front of Moctezuma covering him well, so that he could not be wounded, and accompanied by certain hidalgos and soldiers, they climbed to the roof at the front of the courtyard where the house of the viceroy now stands. It happened that the people below, who were countless in number, were all strangers and did not know Moctezuma. [This is the only narrative in which this statement about the people attacking Moctezuma being strangers occurs-G. M. S.] They were shouting so loudly that they shook the city, and were sending such a volley of stones, spears and arrows that the sky seemed to rain stones, spears, arrows and darts. Therefore when Moctezuma showed his face a little to speak - it was at eight or nine o'clock in the morning - there came toward him from among the flying stones one which was round as a ball, and hit him on the forehead as he stood there between the other two, and he fell. ...Moctezuma, wounded in his head, gave up his soul to his Maker (Author's note: Three days later) at about the hour of vespers...

Similar information was provided to Gonzalo Fernández de Oviedo, ${ }^{12}$ Captain of the Fortress of Santo Domingo and Chronicler to the Emperor Charles V (Historia Géneral y Natural de las Indias, 1535-1557) by conquistadores Juan Cano and Commander Pedro de Alvarado, both attesting that the head injury was produced by a stone "thrown from the outside."

Francisco López de Gómara, ${ }^{17}$ private secretary to Captain Hernán Cortés (La Conquista de Mexico, 1553), repeated the account of Moctezuma's head injury given to him by Cortés himself.

Mestizo author Diego Muñoz Camargo, ${ }^{20}$ a direct descendent of Tlaxcalan Indian nobility, had access to original Indian sources, including a man who had been a Tlaxcalan priest. He reported in Historia de Tlaxcala, written between 1576 and 1591:

De suerte que le tiraron una pedrada con una honda y le dieron en la cabeza, de que vino a morir el desdichado rey. [A stone was hurled at him with a sling and wounded him on the head, from which the unfortunate king died. (Translated by G. M. S.)]

Fray Bernardino de Sahagún, Franciscan priest and contemporary of Cortés, produced The Conquest of Mexico, also known as the General History of the Things of 
New Spain and the "Florentine Codex". ${ }^{9}$ He wrote this work 35 years after the conquest from interviews that his young Indian students had obtained from their elders who were present at the event. In this work, Sahagún did not assign responsibility for Moctezuma's death to anyone. However, later in 1585, he wrote Conquest of New Spain, 1585 Revision, ${ }^{8}$ where in chapter 31 he relates a speech by Cortés as directly blaming the Méxica for Moctezuma's death.

Fray Diego Durán, ${ }^{11,15,16}$ a Dominican priest, in Historia de las Indias de la Nueva España e islas de tierra firme, 1579-1581, describes the king's head injury from a stone as probably a trivial wound:

And saying this, before they could cover Motecuhzoma with the steel buckler and leather shield, one of them threw a stone hitting Motecuhzoma in the forehead, close to the crown of the head, which, even though wounding him, it was a glancing blow, making only a small wound...

Fernándo de Alva-Ixtlixochitl,, 5 descendant of the last king of Texcoco, the cultural center of the Aztec empire, collected Indian paintings and songs that preserved stories and annals and summoned many of the Indian principals, men famed for their knowledge of those stories, to help him interpret these accounts. In Historia de la Nación Chichimeca, 1608, he describes how

They (Aztecs) were enraged and so affronted seeing their king's cowardice so subservient to the Spaniards, that they did not want to hear him, instead they answered him with bad language stressing his cowardice, and they threw at him many arrows and stones; hitting him with one rock on his head, a wound from which he died on the fourth day....

Fray Juan de Torquemada (Monarquía Indiana, 16031613) interviewed conquistador Bernal Díaz del Castillo, and a son of conquistador Pedro de Alvarado. He collected extensive information from indigenous people about their ancestors and incorporated this material without resolving contradictory and competing points of view. According to 19th-century historian Manuel Orozco y Berra ${ }^{21}$ (whose sympathies were entirely with the Aztec defenders of Tenochtitlan), Torquemada's opinion about Moctezuma's cause of death was that he "leaves it to God's judgment."

The "Tovar Codex", 25 also known as the "Ramírez Codex", and the Relación del origen de los indios que habitan Nueva España según sus histórias, was discovered in the ruined library of the monastery of San Francisco in Mexico City by José Fernández Ramírez in 1878. It probably originated in the late 16th century, and is thought to be based on "Crónica X", a postulated earlier document compiled by Christianized Indians. It describes the head injury of Moctezuma, but diminishes its importance. It has almost identical language to Durán's, and it is believed to have been the early source to which he referred. These documents appear to be common sources for Durán's work, although it is uncertain which was first.

\section{Moctezuma's Head injury}

Although there is no valid information as to whether Moctezuma lost consciousness, the witnesses agree that he was felled by a missile thrown with a sling:
There came toward him from among the flying stones one which was round as a ball, and hit him in the forehead as he stood there between the other two, and he fell... (Aguilar, ${ }^{1}$ Spanish source.)

He was hit in the middle of the forehead by a rock thrown with a sling, that he felt it was (a) lethal (wound)... (Vázquez de Tapia, ${ }^{27}$ Spanish source.)

(They) threw a stone with a sling and wounded him on the head, that caused the unfortunate king's death." (Muñoz Camargo ${ }^{20}$ Indian source.)

Moctezuma fell after being hit on the forehead. It is known that sometime after his injury, Moctezuma was conscious and able to converse, ${ }^{4,28}$ acknowledging that he knew he was mortally wounded and would die soon. ${ }^{27} \mathrm{He}$ refused treatment and food, as attested by Bernal Díaz del Castillo: "Although they begged him to care for himself and to eat something and said good words about it to him, he would not..." Vázquez de Tapia adds:27 "Moctezuma thanked the Marquiz (Cortes), asked him not to be sorry and not to take effort to treat him, as he was mortally wounded, would not survive and would die soon..."

We read that Moctezuma was in pain. Bernal Diaz del Castillo comments about Father Olmedo's regrets about not helping Moctezuma, "that he (Olmedo) should have ordered them to give Montezuma something to deaden the pain."

\section{The Fate of Moctezuma's Body}

\section{Cortés: ${ }^{3}$}

I told two of the Indians that were captive to carry him on the shoulders to the people. What they did with him I do not know; only the war did not stop because of it.

\section{Fray Francisco de Aguilar: ${ }^{1}$}

In the quarters where he was lodged there were other great lords being held with him and with the approval of the captains Cortes had them killed, leaving not a single one. Later the bodies were removed and thrown in the porticos where the stores are now...

\section{Bernardino Vázquez de Tapia:27}

They put him in a burlap sack and gave him to some Indians who were Moctezuma's servants to take him away; as the Mexican warriors saw him (dead), they thought that we had killed him...

\section{The Nature of Moctezuma's Head Injury}

Can a head injury from a sling projectile be lethal? The answer is yes. The sling is one of the oldest weapons of war. ${ }^{8,9,22}$ Ballistically, round or plum-shaped missiles are most efficient. Aguilar specifically describes the offending stone, "one which was round as a ball." A stone weighing 50 grains $(1.14 \mathrm{oz})$ thrown at $120 \mathrm{ft}-\mathrm{lb}(81.81 \mathrm{mph})$ would impact an area of 0.75 inches, producing a 1.2-inch wound,${ }^{14}$ and delivering impact energy of $16.0 \mathrm{ft}-\mathrm{lb}$. Moreover, a small shot of this size is capable of a flat trajectory up to 75 yards.$^{13}$ Heavier projectiles can be lobbed up to 200 yards. $^{24}$ 
We have insufficient data to speculate about the specific nature of the intracranial pathological entity caused by the head trauma likely responsible for Moctezuma's death, but the injury was so severe that he died 3 or 4 days later in the evening hours. ${ }^{1,17,27}$ Fray Francisco de Aguilar stated: "Moctezuma wounded in his head, gave up his soul to his maker at about the hour of vespers..." The emperor's death came to Bernal Díaz del Castillo as something of a surprise: "When we least expected it, they came to tell us he was dead..." He added that "(Father) Olmedo did not believe he would die from his wounds...." We should remember that the Spaniards were engaged in a continuous and heavy battle for survival throughout these days, with neither time nor effective resources for diagnosing or treating Moctezuma's injury. ${ }^{25,26}$

\section{Unresolved Issues}

Most, but not all, of the primary sources of information about Moctezuma's death came from among the conquistadors themselves. This raises the question of bias, as the Emperor was their prisoner at the time. Of major importance, and strong examples of the divergence of opinions, are the statements by Francisco de Aguilar, ${ }^{1}$ one of the Spanish soldiers charged with protecting Moctezuma at the time of his injury. After the Conquest of Mexico, disillusioned with his participation in it, Aguilar became a friar and did not write his Relación Breve de la Conquista de Nueva España until 1565. Like most clergy of the time, Aguilar favored the Indian cause. Despite that bias, Aguilar wrote about Moctezuma's head injury and subsequent death as having been produced by a flying stone hurled at him by his own people while he was addressing them. On the other hand, Fray Diego Durán,,$^{11}$ who in his writings recognized Aguilar's sympathy for the Indians, still adhered in his own opinion to the theory that Moctezuma was assassinated by the Spaniards inside his palace.

\section{Moctezuma's Head Injury and Subsequent Death Hastened the Downfall of the Aztec Civilization and Changed the Course of Mexican History}

The Spaniards owed their entry into Mexico solely to the fact that Cortés was believed by Moctezuma to be an astro-magical force. For that same reason, Cortés was able to gain entrance to Moctezuma's own palace and make Moctezuma a virtual prisoner there. Even under these circumstances, Moctezuma was never without influence over his own people, nor did he cease to act in the best interests of his nation. He even managed to accomplish two important strategic feats for his country: first, he made a secret attempt to conspire with Pánfilo de Narváez (a captain sent by the governor of Cuba) to arrest Cortés. ${ }^{23}$

Second, and most importantly, under the guise of interceding with the Aztec leadership to open the Aztec markets (as Cortés wished), he tricked Cortés into releasing his brother Cuitlahuac, the lord of Iztapalapan, who had been chained as a prisoner within the palace with other high-ranking lords. Instead of opening the markets, Cuitlahuac was directly appointed acting sovereign ${ }^{21,23}$ and as such ordered the immediate annihilation of the Spanish contingent.
Although the Aztecs disapproved of their Emperor's apparent acquiescence to the Spaniards, their respect for Moctezuma remained. When circumstances deteriorated for the Spaniards and they were facing death in the Aztec capital, Moctezuma agreed to intercede with his subjects on their behalf so that the Spaniards would have safe conduct, as they were ready to leave the city. Upon recognizing their Emperor, the Aztec crowd temporarily ceased their attack on the Spanish quarters, respectfully listening to Moctezuma's plea. Then they responded: "Dear Lord of ours, we feel deeply for your misfortune. But we had to elect another to be our Lord, forgive us. We pray for you every day. When all is done and we have destroyed those whom the gods have ordered us to destroy, we shall pay you yet greater respect than before." ${ }^{2,10}$ However, dissension in the crowd occurred, followed by renewal of their attack on the Spaniards; undoubtedly some wished to hurt Moctezuma as well. It was then that he was hit.

\section{Direct Consequences of Moctezuma's Death}

Had the Spaniards been allowed to withdraw and had Moctezuma's death been averted, the Aztec government and military could have continued, perhaps even under Moctezuma's command, with government leadership intact. The emperor's death eliminated Cortés's last bargaining tool, ${ }^{19,23}$ forcing him into a hasty and disastrous withdrawal from the city. These events also sealed the fates of the kings of Texcoco and Tacuba, the lord of Xochimilco, the military governor of Tlalteloco, and other Aztec lords who had been imprisoned along with Moctezuma. All of them were executed by the Spaniards before their flight from Tenochtitlan. ${ }^{26}$

The death of all of these leaders and of Moctezuma deprived the Aztec nation of pivotal government leaders and experienced military figures from both the Aztecs and the allied nations during their military restructuring and in the preparation of a successful resistance to the likely return of the conquistadores. Added to these critical losses was the devastation produced in Tenochtitlan by smallpox, which killed probably $38 \%$ of the city's population in the ensuing 9 months. In addition, there was a gradual loss of support from some neighboring Indian nations. Cortés resumed hostilities against the Aztec capital in April 1521, using siege warfare and adding burn-and-destroy guerrilla tactics. He combined land and naval operations and brilliantly used his artillery, superior weapons, infantry, and mounted forces. Despite heroic defense by the Aztecs, the fall of Tenochtitlan came on August 13, 1521, and with it, the end of the Aztec empire. As argued by Nigel Davies, ${ }^{4}$ even should Cortés's army have been driven out of the land and the destruction of the Mexican Empire not occurred at that point, in time Spain or another European power would have eventually conquered Mexico. In that event, the circumstances would have been very different for all involved. It would have been the fight of an invading army against a fully restructured Mexican army, with battles raging on many fronts. The Mexican army would have use of fully perfected battle tactics of feints and concealment, with which the Europeans were not skilled or familiar. Just 4 years before Cortés's arrival, Moctezuma II had mustered 100,000 seasoned troops in a war of anni- 
hilation against the Chichimec Alliance. ${ }^{22}$ With Moctezuma alive to provide experienced leadership, the conquest of the Aztecs would have been later and much harder. Victories had been abundant and definitive when Moctezuma was in command. His death precipitated a series of cascading events that would rapidly result in the destruction of the Aztec empire, ending the primacy of the Aztec nation and changing the history of the Méxica people.

\section{Conclusions}

In my comparative analysis of multiple sources of information from witnesses to the events leading to the death of Moctezuma, there is overwhelming consistency in statements from those individuals describing the head injury from the sling shot, despite the fact that these accounts were given by witnesses of different ethnicities, nationalities, and persuasions. Some of the statements given by Spaniards were taken as part of formal inquiries. ${ }^{12}$ This testimony is in strong contrast to the discordant and incohesive native texts. ${ }^{26}$ Clinically, this head injury could have certainly resulted in Moctezuma's death.

Based on these findings, this author holds little to no doubt that the emperor died as a result of a head injury inflicted by the Aztec people, who mistakenly believed that he had abandoned them. In reaching this opinion regarding Moctezuma's head injury as likely causing his death, I have attempted to be neutral and impartial, but, as Benjamin Keen has stated, ${ }^{15}$ no matter how remote from the present is the subject of historical inquiry, such objectivity may be unattainable: "The extreme diversity of views expressed by writers who drew upon much of the same body of facts, and the passion they displayed, arose not only from the inherently controversial nature of the subject but from the premises and partialities they themselves brought to the subject."'15

\section{References}

1. Aguilar F: Relación breve de la conquista de la Nueva España, in Vazquez G (ed): La Conquista de Tenochtitlan, Cronicas de America 40. Historia 16. Madrid: Dastin, 1988, pp 145-146

2. Collis M: Cortes and Montezuma. New York: Avon Books, 1954, pp 190-192

3. Cortes H: Letters from Mexico. Padgen A, ed. New Haven, CT: Yale University Press, 1986

4. Davies N: The Aztecs. New York: Putnam and Sons, 1973, p 283

5. de Alva Ixtlilxóchitl F: Historia de la Nación Chichimeca. Madrid: Dastin, 2010

6. de Alva Ixtlilxóchitl F: Visión de la Conquista. Mexico City: Fondo de Cultura Economica, 2006

7. de Fuentes P: The Conquistadors. First-person Accounts of the Conquest of Mexico. Norman, OK: University of Oklahoma Press, 1993, pp 153-154
8. de Sahagun B: Conquest of New Spain: 1585 Revision. Cline HF and Cline SL, eds and trans. Salt Lake City: University of Utah Press, 1989

9. de Sahagun B: Florentine Codex: General History of the Things of New Spain. Anderson AJO, and Dibble CE, eds and trans. Santa Fe: School of American Research, 1975, Vol 14, pp 65-66

10. Diaz del Castillo B: Historia Verdadera de la Conquista de la Nueva España. Mexico City: Porrúa, 1992, pp 252-253

11. Durán D: Historia de las Indias de Nueva España e Islas de la Tierra Firme, ed 2. Garibay Kintana ÁM, ed. Mexico City: Porrúa, 1984, pp 551-556

12. Fernandez de Oviedo y Valdes G: Historia General y Natural de las Indias, Islas y Tierra Firme del Mar Oceano. de Los Rios JA, ed. Madrid: Real Academia de la Historia, 1853, Vol 3

13. Gabriel RA: The Great Armies of Antiquity. Wesport, CT: Praeger, 2002, p 30

14. Gabriel RA, Metz KS: From Sumer to Rome. The Military Capabilities of Ancient Armies. Westport, CT: Greenwood Press, 1991, pp 59, 74-75

15. Keen B: The Aztec Image in Western Thought. New Brunswick, NJ: Rutgers University Press, 1990

16. Leon-Portilla M (ed): The Broken Spears. The Aztec Account of the Conquest of Mexico. Kintana Garibay ÁM, Kemp L, trans. Boston: Beacon Press, 1962, p 83

17. Lopez de Gomara F: Cortes: The Life of the Conqueror by his Secretary. Simpson LB, ed. Oakland, CA: University of California Press, 1964, pp 212-213

18. Madariaga S: Hernan Cortes. Conqueror of Mexico. London: Hollis \& Carter, 1968, p 338-339

19. Marks RL: Cortes: The Great Adventurer and the Fate of Aztec Mexico. New York: Alfred Knopf, 1993

20. Muñoz-Camargo D: Historia de Tlaxcala. Barcelona: Red ediciones, 2012

21. Orozco y Berra M: Historia Antigua y de la Conquista de Mexico. Mexico City: Porrúa, 1978, pp 366-382

22. Pohl JMD: Aztec, Mixtec and Zapotec Armies. Oxford, UK: Osprey, 1991

23. Prescott WH: The Conquest of Mexico and Peru. New York: Washington Square Press, 1966, p 141

24. Richardson T: The ballistics of the sling. Slinging.org. (http://slinging.org/index.php?page=the-ballistics-of-thesling---thom-richardson) [Accessed April 23, 2015]

25. Thomas H: Conquest: Montezuma Cortes and the Fall of Old Mexico. New York: Simon and Schuster, 1993, pp 400-406

26. Vazquez G: Moctezuma. Protagonistas de America. Historia 16. Madrid: Quorum, 1987, pp 144-157

27. Vazquez de Tapia B: Relación de méritos y servicios del conquistador Bernardino Vázquez de Tapia, in Vazquez G (ed): La Conquista de Tenochtitlan, Cronicas de America 40. Historia 16. Madrid: Dastin, 1988, p 174

\section{Correspondence}

Gonzalo M. Sanchez, 9898 N. Sumter Creek Pl., Tucson, AZ 85742. email: gonzalosanchez411@gmail.com. 